\title{
O TEMPO É O ESPETÁCULO
}

\section{Mariângela de Andrade Paraizo \\ UFMG}

\begin{abstract}
RESU MO
Neste estudo se propõe uma leitura de Vestido de noiva, de Nelson Rodrigues, em que se pretende mostrar que a maior originalidade dessa peça consiste em dar ao tempo um tratamento que revoluciona sua representação.
\end{abstract}

\section{PALAVRAS - CHAVE}

Nelson Rodrigues, tempo, representação

El tiempo es un río que me arrebata, pero yo soy el río; es un tigre que me destroza, pero yo soy el tigre; es un fuego que me consume, pero yo soy el fuego.

Jorge Luis Borges

A atualidade das peças de Nelson Rodrigues é um reflexo da atemporalidade dos temas com que trabalha e da arte com que o faz. Tratam-se de peças inúmeras vezes encenadas, cuja leitura é sempre instigante e provocadora.

Há quem justifique de outra maneira o impacto causado pelas questões levantadas pelo teatrólogo. Por exemplo, no VI Festival de Teatro de Curitiba, realizado em março de 1997, Antônio Abujamra, que dirigia O casamento, declarou:

Nos propomos a mostrar que se Nelson continua chocando as platéias como fazia na década de 50 é porque o Brasil está cada vez mais atrasado culturalmente, socialmente e economicamente.'

Não pretendo discutir esse apregoado atraso brasileiro, em uma época em que, acredito, os próprios conceitos de atraso ou de progresso deveriam estar em questão. Entretanto, cabe observar que o mal-estar causado pelo teatro de Nelson Rodrigues faz parte de sua proposiçāo estética e que atribuí-lo apenas às condições de sua recepção é reduzir as dimensões de seu trabalho.

Para tanto, é necessário fazer uma leitura de Vestido de noiva, procurando investigar a atualidade de seu discurso, não apenas pelo viés da atemporalidade que seria intrínseca a qualquer obra de arte, mas também através de elementos em seu texto que nos proporcionam uma reflexão sobre a representação do tempo condizente com a época em que vivemos.

Quando de sua primeira encenação, em 1943, surpreendeu e renovou o teatro brasileiro. Na ocasião, a peça foi montada pelo polonês Ziembinski, e contou com um

\footnotetext{
${ }^{1}$ Em Olivelra. Três vezes Nelson Rodrigues, p.4.
} 
cenário criado por Santa Rosa. O elenco foi composto de amadores, um grupo intitulado Os Comediantes, cuja posição de destaque na sociedade carioca contribuiu para atrair as atenções e subvenções que o espetáculo recebeu. Grande quantidade de escritores e de jornalistas leu o texto com antecedência e Vestido de noiva mereceu um grande destaque na imprensa, mesmo antes de ir ao palco. No entanto, se esses elementos favoreceram seu sucesso naquela ocasião, não seriam suficientes para justificar a eficácia com que parece chegar aos palcos e platéias durante todos esses anos.

Mais de meio século depois de escrita, a peça está longe de perder o seu caráter desconcertante. Com os olhos de hoje, podemos ver, nessa obra, uma representação do paradoxo que ainda vivemos no final do milênio: a percepção da reconstituição do tempo como sendo simultaneamente restauração e ruína, gesto criador que refaz como desfeita a narrativa que se representa.

Em Vestido de noiva, o espetáculo começa fora do palco, onde chegam apenas os ruídos do acidente em que Alaíde é atropelada. Entre a vida e a morte, a personagem entrará em cena pela via da alucinação, à qual será conduzida através de lembranças do que viveu ou que foram forjadas pelo que leu, imaginou ou desejou. Em contrapartida, esses momentos que nāo aconteceram fornecerão o suporte para que ela reconstitua sua história e encontre seu fim.

No roteiro de Nelson Rodrigues, o cenário se divide em três planos - da alucinação, da realidade e da memória - entrelaçados pelo trânsito da protagonista. A maioria dos episódios transcorre no mesmo casarão, lugar por que teriam passado as personagens principais, em épocas diferentes.

Nesse entrelaçamento dos planos, a repetição é um laço fundamental. Tanto a reiterada encenação de alguns episódios, como a insistência de traços que vão conferindo sentido ao enredo, pela via do absurdo. Dentre estes, o rosto de um mesmo ator que representa várias personagens e um véu que impede a identificação de uma mulher.

Em seu delírio, Alaíde pensa reconhecer o marido em todos os homens com quem conversa, e o espectador deve compactuar com essa impressão, uma vez que ele próprio está sujeito à mesma repetição. Mas, se o rosto do marido está sempre presente, o da irmã está interditado: Alaíde lembra-se de uma mulher chamada Lúcia, bem como de uma que está de véu. Entretanto, custa a se dar conta de que são uma única pessoa.

Desse modo, se um mesmo semblante está tantas vezes visível que praticamente já não particulariza ninguém, há uma face velada que insiste em se fazer notar pelo que nela se mostra como negado, ou seja, pela fisionomia que insiste em evidenciar seu ocultamento. $O$ jogo de presença e ausência é também pulsação de vida e morte, e há nele uma tensão identificada no triângulo amoroso e bélico que sustém as relações familiares.

Mediando alucinação e memória, cumprindo uma função de escuta que dirige a restauração do tempo, encontramos Madame Clessi, morta por seu jovem amante e que faz parte de um tempo ainda mais remoto. Alaíde leu o seu diário bem como as notícias de jornais, obtendo as informações com que recompor a história dessa dama das noites cariocas, antiga moradora do casarão que agora pertence a sua família. Clessi e Alaíde ocupam o mesmo quarto, ainda que só o espaço arquitetônico seja o mesmo: vieram de mundos social e culturalmente apartados e viveram em épocas diferentes. 
A maneira com que Alaíde interpela Clessi, quando de seu primeiro encontro, situa o lugar que ela deve ocupar nessa construção: "Não sei o que é que eu tenho. É uma coisa - não sei. Por que é que eu estou aqui?"'

Propondo à outra mulher uma questão cuja resposta só ela mesma poderia encontrar, apresentado-se por seu não-saber, é ao Outro que ela se dirige, deflagrando o processo de interrogar o limiar de um ponto cego que se furta a uma representação e que será apenas delineado entre memória e esquecimento. A morte é umbral, horizonte e instância desse processo em que só se reconstitui a história para que ela alcance um fim.

Quando entra em cena depois do atropelamento, Alaíde se dirige ao passado que desconheceu e que, no entanto, vai ajudá-la a reconhecer o presente que não pode suportar. Embora os planos da memória e da alucinação componham a maior parte das cenas, é a iminência da morte da moça que marca o ritmo de toda a peça, tempo limite que se representa em seu desvanecimento, espaço do morto a partir do qual a vida se vislumbra.

Um relógio é a referência do local onde ela foi atropelada, na Glória. Nos episódios reconstituídos, várias vezes as personagens consultam seus relógios: durante a preparação para o casamento de Alaíde ou no velório de Clessi, apressando-se ou tentando antecipar os acontecimentos. O presente da peça, chamado de plano da realidade, é o tempo da agonia de Alaíde, marcado pela urgência dos médicos, ao tomar decisōes e executá-las, somada à expectativa dos jornalistas, entre a notícia do atropelamento e a da morte, urgência e expectativa que se contrapõem à indiferença deles todos perante o episódio. Exercem seus papéis com frieza e interesse profissional. Os espectadores são verdadeiramente as únicas testemunhas envolvidas pelo drama da protagonista que o vai apresentando, expondo-o através das ruínas do tempo que se constrói.

No começo da peça, Alaíde nos diz: "Não tenho memória — sou uma mulher sem memória." Entretanto, para que recomponha seu passado, o preço é que ela se torne cada vez mais uma mulher só memória. Na realidade, é apenas com recordações que ela conta para refazer a sua vida, e nessas lembranças se mesclam os acontecimentos do dia de seu casamento, as leituras que fez do diário de Clessi, as consultas às notícias de jornais, cenas retiradas de trechos de ficção - como de La traviata e de E o vento levou. São revividas suas próprias fantasias, como a de visitar o bordel onde vivia Clessi, observar as mulheres dançando e ser até abordada por um dos freqüentadores, bem como será encenado o seu desejo de matar o marido, que ela não sabe se levou a termo. Em seu delírio, chega a ouvir as notícias de jornal anunciando o crime que teria cometido.

O presente da encenação é o tempo da agonia, no qual todos os tempos se dão em espetáculo. À medida que sua história vai sendo reconstituída, seu corpo fraturado sofre as intervençōes cirúrgicas - inclusive uma amputação - e sua vida vai-se desfacelando. Entre refazer e desfazer-se, é tempo de carnaval, no sentido que Bakhtin atribui ao termo: "a festa do tempo que tudo destrói e tudo renova." 4

\footnotetext{
${ }^{2}$ Rodrigues. Três peças: Álbum de família, A falecida e Vestido de noiva, p.22.

${ }^{3}$ IBIDEM. p. 14.

${ }^{4}$ Bakhtin. Problemas da poética de Dostoiévski, p.107.
} 
Nessa peça, o vestido de noiva empresta um caráter de ritual aos acontecimentos, evocando o tempo mítico em que a renovação é também prenúncio de morte: Clessi o vestiu depois de morta, Alaíde deve morrer porque o vestiu e Lúcia o usará logo depois de tirar o luto pela morte da irmã, que lhe entregará o buquê de casamento.

Há, pois, uma inversão no sentido habitual da representação carnavalesca, uma vez que, no tempo do mito que ela atualiza, o ritual é promovido para que se alcance a renovação da vida e não a da morte, como aparentemente ocorre na peça. Entretanto, ainda que nāo sobreviva ao atropelamento, a vida da protagonista será reconstituída na representação que dela se fará. Além disso, persiste a ótica subvertida do carnaval que permite a aproximação de Alaíde e Clessi.

Há vários trechos do diálogo entre elas nos quais observamos que as duas mulheres sabem que vivem uma situação absurda. É interessante destacarmos pelo menos este:

\section{CLESSI}

Você está fazendo uma confusão! Casamento com enterro!... Moda antiga com moda moderna! Ninguém usa mais aquele chapéu de plumas, nem aquele colarinho!

Alaíde

(Agoniada.)

Tudo está tão embaralhado na minha memória! Misturo coisa que aconteceu e coisa que não aconteceu. Passado com o presente! (Num lamento.) É uma misturada! ${ }^{5}$

É evidente que o texto não traz a nota da alegria que comanda a festa do livre contato entre as pessoas, mas o tempo é tomado pelo seu avesso, restaurado no momento em que já não pode ser contado em uma cronologia convencional, quer pensemos em uma evolução do passado para o futuro ou, ao contrátio, do futuro para o passado. Já não se trata de tomá-lo como um fio, mas como uma rede, em que os vazios contam tanto quanto as malhas que os delimitam.

À força de repetir fragmentos de seu diálogo com Lúcia, Alaíde acaba por reconstituir o dia do casamento, no qual é informada da traição da irmã e do noivo, de sua própria traição e da necessidade de sua morte para a união dos dois. O que se observa é que basta um traço para que se refaça o tempo que passou, traço que, na peça, será fornecido pelo vestido de noiva, que lhe dá título. Ainda que os três planos sejam uma evocação do todo, é através do traço metonímico que se vai efetivamente promover a recomposição do passado, e essa recomposição é mais lacunas que compacidade. Para a execução dessa tarefa, não é necessário mais tempo que o bastante: como tão precisamente nos propõe a psicanálise, a lógica que dimensiona o tempo é causada pelo desejo.

Em 1958, Sérgio Cardoso procedeu a uma montagem da peça em que optou por não dividir o palco em três planos, mas apenas em dois: o da alucinação e o da realidade. E se justificou:

Na parte da alucinaçāo, o plano da memória aparece inicialmente com toda a lucidez, para se fundir lentamente com o plano da realidade, acabando por formar um plano único. E na parte da realidade, temos a realidade certa, concreta, imutável, constituindo um plano oposto, quase como o verso e o reverso de uma medalha. ${ }^{6}$

\footnotetext{
${ }^{5}$ Rodrigues. Três peças: Álbum de família, A falecida e Vestido de noiva, p.77.

${ }^{6}$ Em MAGALDI. Nelson Rodrigues: dramaturgia e encenaçōes, p. 88.
} 
Creio que a opção vai de encontro a pelo menos um dos aspectos mais revolucionários que a peça traz, ou seja, o que se utiliza dos três planos temporais para desfazer o sentido da representação do tempo, com o qual estamos acostumados a contá-lo. A idéia de uma memória com "toda a lucidez", ou de uma realidade "certa, concreta, imutável" é bem mais artificial que a aparente confusão que o texto original de Nelson Rodrigues pōe em cena. É justamente por representar uma situaçāo limite que a peça deve abdicar do imutável, da certeza ou da própria noção de totalidade, para produzirse como espaço de transformaçōes. No confronto entre memória e alucinação, entre vivido e inventado, a realidade será representada, dando lugar à construção do fantasma que viabiliza a inscrição do sujeito pela via discursiva. Abdicando-se da oscilação entre fatos e fantasias, fecha-se um espaço imprescindível.

Vestido de noiva põe o tempo em cena e expõe a impossibilidade de se apreendêlo, em uma representação que, com ser a encenação de algo a que o público nunca tinha assistido, é fiel aos devaneios, bem como aos episódios que efetivamente tiveram tempo de acontecer às personagens envolvidas, incluindo os próprios espectadores e leitores. Retratando um drama doméstico, coloca em questāo a condição humana e em xeque os valores que sustentam e embaraçam as relações familiares. Ficção e realidade disputam no palco as atenções do público, e expõe-se uma outra faceta de nosso cotidiano: cada um de nós sabe o quanto nos entregamos aos sonhos para que possamos produzir nossa realidade. A singularidade da experiência de Alaíde não reside, pois, na coexistência dos planos, nem na incidência de mais de um deles no processo de contar a sua história, mas em sua forma de perceber e de representar as diversas instâncias em que eles transparecem e se cruzam.

Ao colocar as personagens num tempo de suspensão, Nelson Rodrigues promove uma outra forma de representação, verificando o que o mito nos informa desde sempre: o tempo não está fora de nós, nem corre linearmente. É nossa matéria perecível e mortal que o estofa e lhe dá o sentido irreversível com que nos acostumamos a pensálo. Ao se confrontarem o tempo histórico e o tempo mítico, as duas representaçōes se põem em questão: a do primeiro, porque não volta; a do segundo, porque não passa.

Em prosa e em verso, as letras nacionais já haviam realizado a experiência revolucionária que representou, entre nós, o movimento modernista, formado pela dissonância das vanguardas que aqui chegavam. No teatro, Vestido de noiva se encarrega de promover a primeira grande subversāo. Com seu caráter quase cinematográfico, empresta um novo ritmo e uma nova dicção à dramaturgia brasileira.

Finalmente, se o teatro de Nelson Rodrigues denuncia complicadas e mortíferas relações familiares, esse não é o seu traço mais marcante ou original. Nesse aspecto, seu enfoque, embora muito instigante, pode ser considerado inclusive moralista, como tantas vezes já foi dito. A revolução que Vestido de noiva nos propõe e cuja atualidade se mantém não está nas linhas ou nas entrelinhas de seu texto, mas em sua urdidura, que ignora o tratamento convencional que o tempo recebe na narrativa que se encena, para representar sua trama feita de fios, vazios e imaginação.

\section{A)}




\section{ABSTRACT}

In this study, the reading of Vestido de noiva, by Nelson Rodrigues, is in our pursuit, when we intend to show that the genuinely of this play consists in giving time a treatment which revolutionizes its representation.

\section{KEY WORDS}

Nelson Rodrigues, time, representation

\section{REFERÊNCIAS BIBLIOGRÁFICAS}

Bakhtin, Mikhail. Problemas da poética de Dostoiévski. Trad. Paulo Bezerra. Rio de Janeiro: Forense-universitária, 1981.

BORGES, Jorge Luis. Obras completas. 18ª reimpressão. Buenos Aires: María Kodama y Emecé editores, 1989.

Castro, Ruy. O anjo pornográfico; a vida de Nelson Rodrigues. São Paulo: Companhia das Letras, 1995.

LACAN, Jacques. Escritos. Trad. Vera Ribeiro. Rio de Janeiro: Jorge Zahar Editor, 1998.

Magaldi, Sábato. Nelson Rodrigues: dramaturgia e encenações. 2 ed. Sāo Paulo: Perspectiva, 1992.

Oliverra, Roberta. Três vezes Nelson Rodrigues. Rio de Janeiro: Jornal do Brasil, Caderno B, 14/03/97. p.4.

PAz, Octavio. El arco y la lira. 3 ed. México: Fondo de Cultura Economica, 1992.

Rodrigues, Nelson. Três peças: Álbum de família, A falecida e Vestido de noiva. São Paulo: Círculo do Livro, s/d. 